\title{
Gravity driven dewatering systems for landfill expansion
}

\author{
S. A. Smith. \& J. A. Smyth \\ Richardson Smith Gardner and Associates, Inc, USA
}

\begin{abstract}
A landfill site near the east coast of the United States in North Carolina has utilized a permanent gravity driven ground water dewatering system to construct lower liner grades, decrease a soil deficit at the site and increase landfill capacity. A variety of methods based on published data and field investigations were used to determine the design and impact of the dewatering system for the site. The design of such systems is highly dependant on the hydraulic conductivity of the aquifer and should be scrutinized based on the extent and impact of the proposed dewatering system. The final design of the dewatering system should include a judgement of the collective aquifer testing results to adequately size the system and to evaluate the schedule of implementation based on the time required for full drawdown.
\end{abstract}

Keywords: aquifer dewatering, landfill construction.

\section{Introduction}

The protection of ground water is an integral part of the design of a solid waste landfill. One of the fundamental concepts of modern landfill design has been to prevent the migration of leachate (stormwater that has been in contact with the waste) into the ground water below the landfill. U.S. Federal regulations (40CFR258.40) require that modern landfills include a low permeability soil liner and a flexible membrane liner to prevent leachate migration into the ground water below. In certain states, this concept is enhanced by an additional separation requirement between the seasonal high ground water table and the bottom of the landfill liner system. In North Carolina, state regulations require a separation of four (4) feet between the uppermost aquifer and the liner subgrade. In shallow aquifer systems, this requirement results in construction of the landfill 
mostly above the ground surface requiring substantial fill material, earthwork and cost. This project consisted of modelling and designing a permanent gravity driven aquifer dewatering system to allow for deeper construction of the landfill liner system and a decrease in the soil deficit at the site.

\section{Physical setting}

The landfill, located in eastern North Carolina, had already constructed and filled approximately 40 acres of a 200 acre site meeting the 4-foot separation requirement, and all liner requirements. In these 40 acres, seasonal high ground water elevations required that most of the landfill be constructed above grade due to shallow aquifer conditions. This requirement created an overall soil deficit for operation and construction at the site, resulting in off-site borrowing of soils at a higher unit cost. The soil deficit projected at the start of this project was approximately 5 million cubic yards.

The site is located in an upland area adjacent to a steep escarpment down to Bearskin Swamp, which includes Bearskin Creek. The steep topography leading to the swamp was a key element to the dewatering system being driven by gravity in perpetuity.

\section{Site hydrogeology}

The uppermost aquifer is located within the sands, silts and clays of the upper Cretaceous Black Creek Formation. This formation consists of inter-bedded layers of black or dark-gray thinly laminated clays and lenses of sand varying in thickness and grain size (Horton, 1991) [1]. The Black Creek Formation contains an aquitard consisting of an approximately 20 -foot thick clay layer. During initial site investigations many soil borings and piezometers were installed at the site. In general, the soil boring logs confirmed a clean fine to medium sand underlain by the Black Creek aquitard. The aquitard was encountered between 25 and 30 feet below grade. Within the facility boundary, the uppermost aquifer was generally encountered at a depth of 10 to 15 feet below grade. This aquifer is unconfined. Over the last 10 years, the aquifer has exhibited an annual seasonal fluctuation of four (4) feet.

\section{Initial dewatering system modelling}

The first step in initial modelling at the site consisted of reviewing soil boring logs and grain-size analyses from soil samples and comparing these data to published data for dewatering methods based on gradation. This comparison indicated that the soil types encountered at the site fell within the range of sands suitable for gravity drainage.

\subsection{Analytical modelling as a trench}

Leonards (1962) [2] proposed relationships based on Darcy's Law for drainage slots. These slots were patterned after a series of wells placed in close proximity to 
each other such that the intersecting cones of influence provided a uniform drawdown across the length. He developed a series of formulas based on the geometry and the aquifer condition. Equation 1 below models a partially penetrating slot (or trench in this case) in an unconfined aquifer under gravity flow where the peak discharge from a slot (Leonards, 1962) [2] is:

$$
Q_{p}=\left(0.73+0.27 \frac{H-h_{o}}{H}\right) \frac{k x}{2 L}\left(H^{2}-h_{o}^{2}\right)
$$

where: $\quad \mathrm{Q}_{\mathrm{p}}=$ peak discharge rate

$\mathrm{L}=$ drawdown length

$\mathrm{H}=$ static water height

$\mathrm{k}=$ hydraulic conductivity of the soil

$\mathrm{x}=$ length of the slot

$\mathrm{h}_{\mathrm{o}}=$ height of the water in the slot

Additional relationships can be established based on flow net modelling, which similarly apply Darcy's Law to the situation. These modelling techniques provide flow data based on a gradient as a function of the drawdown length and height. Since the Leonards' equation includes the Dupuit-Forchheimer assumption that hydraulic gradient is constant and equal to the slope of the drawdown curve, this analysis is subject to the limit of influence of the slot, which could only be approximated in the early stages of design.

Initial calculations required an assumption of the hydraulic conductivity of the flow layer. Initially, the assumed hydraulic conductivity, based upon grain size analyses, was $1 \times 10^{-2} \mathrm{~cm} / \mathrm{sec}$.

\subsection{Analytical modelling as a well}

Analytical modelling as a well system was also performed as modelling of trenches does not take the elements of time, decreasing gradient and analysis of flow into account. To further analyze aquifer dewatering both the Driscoll equation (Equation 2) [3] and Neuman's Solution (Equation 3) [4] were used to find the yield for a well in an unconfined aquifer:

$$
Q=\frac{K\left(H^{2}-h^{2}\right)}{1.055 \log R / r}
$$

Neuman's solution is as follows (Fetter, 2001) [4]:

$$
h_{o}-h=\frac{Q}{4 \pi T} W\left(u_{A}, u_{B}, \Gamma\right)
$$

where:

$$
\begin{aligned}
& u_{A}=\frac{r^{2} S}{4 T t} \text { (for early drawdown data) } \\
& u_{B}=\frac{r^{2} S_{y}}{4 T t} \text { (for later drawdown data) }
\end{aligned}
$$




$$
\Gamma=\frac{r^{2} K_{v}}{b^{2} K_{h}}
$$

The preliminary analytical results are shown in Table 1.

Table 1: Preliminary modelling results.

\begin{tabular}{|l|l|l|l|}
\hline Solution & $\begin{array}{l}\text { Model } \\
\text { Type }\end{array}$ & $\begin{array}{l}\text { Peak } \\
\text { Discharge }\end{array}$ & Assumptions \\
\hline Leonards & Trench & $0.44 \mathrm{gpm} / \mathrm{ft}$ & \\
\hline Darcy's Law & Trench & $0.07 \mathrm{gpm} / \mathrm{ft}$ & Constant gradient \\
\hline Flow Net & Trench & $0.45 \mathrm{gpm} / \mathrm{ft}$ & Well radius $=0.25 \mathrm{ft}$ \\
\hline Driscoll & Well & $178 \mathrm{gpm}$ & $\begin{array}{l}\text { Time }=0.5 \text { days and } \\
\text { specific yield }=0.3 \text { for late } \\
\text { drawdown conditions }\end{array}$ \\
\hline Neuman & Well & $264 \mathrm{gpm}$ & \multicolumn{2}{|l}{} \\
\hline
\end{tabular}

The Leonards and Flow Net analyses yielded similar results, however, since Darcy's Law assumed an average constant gradient, the drawdowns were reduced. The well models were significantly different. This is at least partly due to the allowance for early and late discharge in the Neuman Solution. Although these model types (trench and well) do not yield results that can be directly compared, the trench model results were useful for pipe and trench sizing, whereas the well model information was useful for computer modelling.

\subsection{Aquifer recharge and infiltration modelling}

The dewatering system for use under the landfill cell had to insure that aquifer recharge by storm water would not allow the water table to rise to within four feet of the landfill liner subgrade. Therefore, modelling of aquifer recharge and infiltration was required.

Recharge is generally assumed to be infiltration associated with rainfall. Infiltration was considered to be the value of precipitation remaining after runoff and potential evapotranspiration is removed. For the subject site, a value of 12 inches was determined after evaluation of water balance from historical meteorological data.

Three analytical methods were used to evaluate recharge: Leonards equation (Equation 4) for the height of the rebound between two partially penetrating trenches, Fetter's evaluation of recharge to an aquifer system (Equations 5 and 6), and McWhorter's evaluation of recharge (Equation 7) which assumes trenches at equal elevations on each side. These equations are shown below (Leonards, 1962 [2], Fetter 2001 [4], McWhorter, 1985 [5]):

$$
h_{d}=h_{o}\left[\frac{C_{1} C_{2}}{L}\left(H-h_{o}\right)+1\right]
$$

where the values of $\mathrm{C} 1$ and $\mathrm{C} 2$ can be determined from Leonards C-Factor graphs. 


$$
d=\frac{L}{2}-\frac{K}{\omega} \frac{\left(h_{1}^{2}-h_{2}^{2}\right)}{2 L}
$$

to ascertain ground water divide location

$$
h_{\max }=\sqrt{h_{1}^{2}-\frac{\left(h_{1}^{2}-h_{2}^{2}\right) d}{L}+\frac{\omega}{K}(L-d) d}
$$

to ascertain the height of water at the ground water divide

$$
h_{\max }^{2}=\frac{W L^{2}}{4 K}+h_{o}^{2}
$$

Preliminary modelling for rebound of trenches at 500 foot spacing and an impact of 12 inches of annual recharge revealed comparable results with rebound ranging from $<0.1$ feet (Fetter) to 0.6 feet (McWhorter).

\section{Aquifer pump testing}

In order to more accurately determine the hydraulic conductivity and radius of influence of dewatering across the landfill cell, aquifer pump testing was performed. The test consisted of a 6-inch diameter pump test well and a series of 2-inch diameter piezometers to monitor drawdown. The pump test was performed in the uppermost aquifer, above the Black Creek confining unit and was run for a minimum of 24 hours.

\subsection{Aquifer testing results}

Upon completion of the pump tests, the data from several piezometers were analyzed using Theis Curves, Neuman's Solution, Cooper-Jacob Straight Line Method and the Theis and Jacob Recovery Method. The results of each pump test revealed very good response curves. The results of the piezometers located in a representative cell of the landfill are summarized in Table 2 below:

Table 2: $\quad$ Pump testing results (Hutchinson, 2002) [6].

\begin{tabular}{|l|l|l|l|l|}
\hline Piezometer & Theis Curves & $\begin{array}{l}\text { Cooper-Jacob } \\
\text { Straight Line } \\
\text { Method }\end{array}$ & $\begin{array}{l}\text { Neuman } \\
\text { Solution }\end{array}$ & $\begin{array}{l}\text { Theis \& Jacob } \\
\text { Recovery } \\
\text { Method }\end{array}$ \\
\hline $\mathrm{PZ}-2$ & $115 \mathrm{ft} / \mathrm{day}$ & $148 \mathrm{ft} /$ day & $115 \mathrm{ft} / \mathrm{day}$ & $116 \mathrm{ft} / \mathrm{day}$ \\
\hline $\mathrm{PZ}-3$ & $73 \mathrm{ft} / \mathrm{day}$ & $70 \mathrm{ft} / \mathrm{day}$ & $58 \mathrm{ft} / \mathrm{day}$ & $116 \mathrm{ft} / \mathrm{day}$ \\
\hline $\mathrm{PZ}-4$ & $115 \mathrm{ft} / \mathrm{day}$ & $141 \mathrm{ft} / \mathrm{day}$ & $115 \mathrm{ft} / \mathrm{day}$ & $116 \mathrm{ft} / \mathrm{day}$ \\
\hline $\mathrm{PZ}-5$ & $180 \mathrm{ft} / \mathrm{day}$ & $211 \mathrm{ft} /$ day & $204 \mathrm{ft} / \mathrm{day}$ & $263 \mathrm{ft} /$ day \\
\hline Average & $120 \mathrm{ft} /$ day & $142 \mathrm{ft} /$ day & $123 \mathrm{ft} /$ day & $152 \mathrm{ft} /$ day \\
\hline
\end{tabular}

\section{Three-dimensional modelling}

In order to better predict the impact of the dewatering system on the surrounding areas, a three-dimensional model was constructed using the Visual Modflow 
program by Waterloo Hydrogeologic (2002) [7]. The model was initially calibrated to steady-state non-pumping conditions based upon data from numerous piezometers and monitoring wells across the site. Bearskin Creek, located to the northeast of the site was used as a general head boundary condition in the model. Once the steady state water table conditions were accurately modelled for the site, additional analysis was conducted to evaluate the effect of dewatering (modelled as pumping) on the overall aquifer system.

Further modelling was also conducted using the TWODAN Program (Fitts, 1994) [8]. TWODAN is a two-dimensional numerical model based on the work of Strack (1991) [9]. TWODAN uses boundary conditions and analytical solutions that are formulated in terms of discharge potential rather than head.

The dewatering activities were modelled for a landfill cell through the use of a pumping well in the sump of the landfill cell to determine the impact to the ground water surface. This scenario was further evaluated over time steps to determine the time required for complete dewatering. Recharge areas were also assigned over the site consistent with annual water balances previously discussed.

A more realistic view of the system was also analyzed by placing a series of smaller wells around the perimeter of the landfill cell. The multiple well array indicated the ground water surface would reach equilibrium more quickly than the single well model. This concept demonstrates the effectiveness of a drainage trench around the perimeter of the facility. Figure 1 shows the model of the aquifer after construction of all landfill cells.

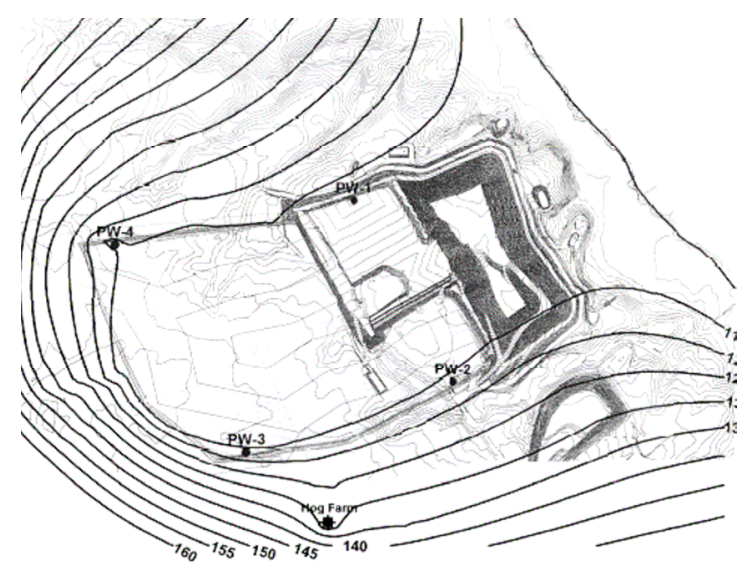

Figure 1: Two dimensional model of full GGI system after landfill construction.

The modelling indicated that the site could be dewatered to a level approximately 15 feet below the static water table and the trench dewatering system would maintain ground water separation requirements for the landfill liner system. 


\section{Demonstration of performance}

The final requirement by State authorities prior to evaluating a landfill permit was construction of a pilot dewatering system to monitor aquifer dewatering and stabilization over time. This included initial grading of the 22-acre landfill cell, installation of the trench dewatering system, and installation of seven (7) piezometers to monitor water levels across the cell.

During site grading, temporary dewatering well points had to be installed so grading and construction of the dewatering trenches could occur in a timely manner. Rebound within the aquifer was conservatively assumed to be 0.5 feet and therefore trench inverts were set at 5 feet below cell subgrade. A total of three dewatering trenches were installed below the landfill cell with a trench connecting them to the dewatering sump. Initially, ground water was pumped from this system as the discharge pipe to Bearskin Creek had not been installed. Due to the cost, the discharge pipe this was the last component of the system to be installed and was only installed after final approval of the system by State authorities.

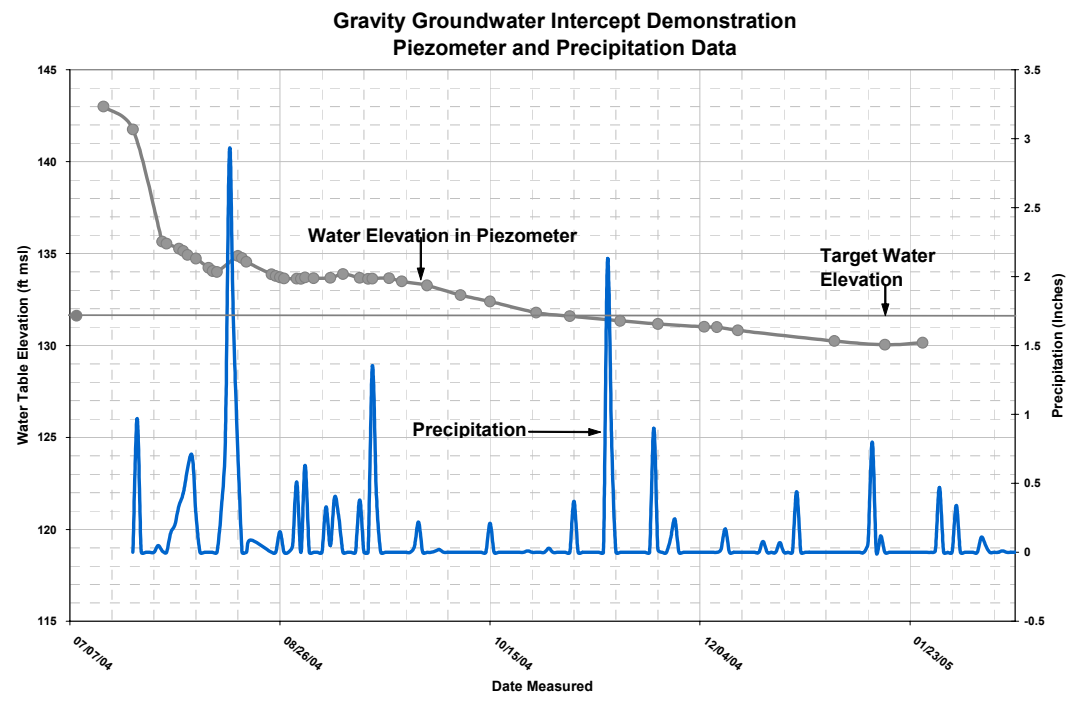

Figure 2: Water table elevations in a demonstration piezometer with precipitation data during the demonstration period.

Upon construction of the dewatering trenches, water levels in each of the seven (7) piezometers were collected on a weekly basis. Each piezometer had a target water level based upon the three-dimensional modelling that would indicate system effectiveness. Additionally, precipitation data was collected during the period of initial system monitoring to evaluate the effect of rainfall on the water levels in the piezometers. The system reached target water levels across the cell within four months with the exception of one piezometer. 
Exploratory excavation was performed around the piezometer and a pocket of clayey soils was discovered. Once these soils were removed, water levels in this piezometer rapidly reached target levels. Overall, rainfall events earlier in the dewatering process had more effect on water levels across the study area than later in the pilot study process when the system was closer to equilibrium, as anticipated. The change in water levels due to dewatering and the effects from precipitation can be seen in Figure 2. Once all target levels were achieved, the site received approval to complete the dewatering system with the discharge pipe to Bearskin Swamp and for landfill cell construction to begin.

\section{Final gravity ground water intercept construction}

Upon approval from the State, the 18-inch diameter discharge pipe was installed by horizontal directional boring. This was installed from a location near the creek up towards the landfill cell. Additional sections were also added for future landfill cell construction. The discharge pipe was specified to be installed at a minimum of $0.1 \%$ slope with surveys performed every 25 feet along the alignment to ascertain pipe slope. The longest run for pipe installation was approximately 1500 feet at an average depth of 25 feet below grade. All slope requirements were achieved with a maximum deviation of 1.5 feet in one area. However, this deviation was below the proposed alignment and not considered to be significant.

\section{Conclusions}

The Gravity Ground Water Intercept System was designed to decrease the soil deficit of the landfill site, to provide close proximity of operational cover soil, to increase landfill airspace and increase the overall stability of the landfill. The system demonstration in the pilot cell was a clear success in meeting all of these goals. By lowering the aquifer approximately 10 to 15 feet, the landfill airspace was increased by approximately 2.5 million cubic yards. Appropriate design corroborated with field testing achieved very positive results in this project.

\section{References}

[1] Horton, J.W. and Zullo, V.A (1991), The Geology of the Carolinas, Carolina Geological Society, Fiftieth Anniversary Volume, The University of Tennessee Press, Knoxville, TN 1991.

[2] Leonards, G.A., (1962), "Foundation Engineering", McGraw Hill Book Company, Inc.

[3] Driscoll, F.G., (1986), Groundwater and Wells, Second Edition, Johnson Filtration Systems, Inc., St. Paul, MN, 1986.

[4] Fetter, C.W. (2001), Applied Hydrogeology, Fourth Edition, Prentice Hall Publishing, Upper Saddle River, NJ, 2001. 
[5] McWhorter, D.B. and Sunada, D.K. (1985), "Ground-Water Hydrology and Hydraulics", Water Resource Publications, Fort Collins, CO.

[6] Hutchinson, P.J. (2002), Water Table-Type Aquifer Stress Report Sampson County Landfill, The Hutchinson Group, Ltd., Murrysville, Pennsylvania, October 4, 2002.

[7] Waterloo (2002), Visual MODFLOW, Version 3.0, Waterloo Hydrogeologic Inc., Waterloo Ontario, Canada, 2002.

[8] Fitts Geosolutions (2003), TWODAN, Fitts Geosolutions, Scarborough, ME.

[9] Strack, O.D.L., Groundwater Mechanics, Prentice-Hall, Englewood Cliffs, NJ, 1989. 